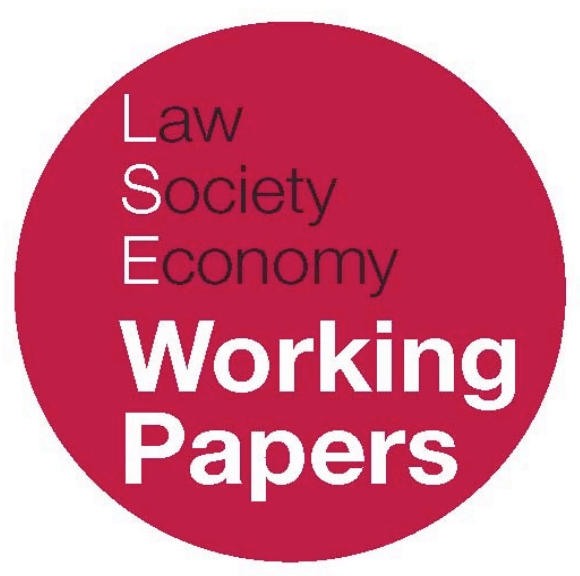

\title{
Authoritarian Liberalism: The Conjuncture Behind the Crisis
}

Forthcoming in E. Nanopoulos and F. Vergis (eds.) The Crisis Bebind the Crisis: The European Crisis as a Multi-Dimensional Systemic Failure of the EU (Cambridge University Press, 2018)

\section{Michael A. Wilkinson}

LSE Law, Society and Economy Working Papers 5/2018

London School of Economics and Political Science

Law Department

This paper can be downloaded without charge from LSE Law, Society and Economy Working Papers at: www.lse.ac.uk/collections/law/wps/wps.htm and the Social Sciences Research Network electronic library at: http://ssrn.com/abstract $=3137329$

(C) Michael A. Wilkinson. Users may download and/or print one copy to facilitate their private study or for non-commercial research. Users may not engage in further distribution of this material or use it for any profit-making activities or any other form of commercial gain. 


\title{
Authoritarian Liberalism: The Conjuncture Behind the Crisis
}

\author{
Michael A. Wilkinson ${ }^{*}$
}

\begin{abstract}
Behind the constitutional crisis of the European Union lies the conjuncture of 'authoritarian liberalism', when politically authoritarian forms of governing emerge to protect the material order of economic liberalism. This constitutional conjuncture can be grasped by integrating into constitutional enquiry the material dynamic between democracy and capitalism, as recently theorised by Wolfgang Streeck. Authoritarian liberalism can then be explored across a much deeper and longer constitutional trajectory, from the interwar breakdown of liberal constitutionalism, to its post-war and post-Maastricht reconstruction, in each case represented by a de-democratisation of the economy. From this perspective, the recent assaults on democracy in the Euro-crisis appear to be a continuation of, rather than divergence from, the normal path of integration. Where this will end remains to be seen. Although authoritarian liberalism is increasingly accompanied by authoritarian illiberal responses, there has not yet been any definitive rupture, with the possible exception of Brexit.
\end{abstract}

\footnotetext{
*Associate Professor of Law, LSE. I would like to warmly thank Eva Nanopoulos and Fotis Vergis for very helpful comments on earlier drafts. A version of this paper is forthcoming in E. Nanopoulos and F. Vergis (eds.) The Crisis Bebind the Crisis: The European Crisis as a Multi-Dimensional Systemic Failure of the EU (Cambridge University Press, 2018).
} 


\section{INTRODUCTION}

In the period spanning nearly a decade from the beginning of the financial crisis to the present, the constitutional state and state-system in Europe has been affected by a series of challenges to its authority and legitimacy. With regard to the European Union, these challenges are fundamental in that they go to the very existence of the project and to the values it professes to be founded on. They seem increasingly inter-connected to the EU and the trajectory of integration rather than merely external to it. For the moment, the EU remains relatively resilient; outside of the UK, appetite for ending the experiment mostly inhabits the political fringes, although even in core countries, anti-European pressures are mounting and Euro-sceptic parties are on the ascendency. What is clear is that the challenges to the current system go as much to the legitimacy of domestic regimes and their political authority as to the EU itself, not least from the fragmentary pressures on the state from below in the context of subnational claims to autonomy. In short, the crisis of authority is not merely of the EU but of the regional state system and the governing order in Europe.

The material conditions for this decade of multiple crises were set in place in the era of the Treaty of Maastricht and the geo-political reconfiguration of Europe that accompanied it. Maastricht established the constitutional structure of EMU, laid the groundwork for the Schengen regime, opened the door to differentiated integration and anticipated the Enlargement of Europe to the East. It also marked a change in the material balance of power, re-unification inaugurating the path to a 'German Europe', and the end of any 'really existing alternative' to liberal capitalism unleashing a neo-liberal ideological hegemony, with not only centrists but erstwhile critical theorists calling an end to emancipatory projects. ${ }^{1}$

This process of de-politicisation reached its apogee in domestic contexts of a 'third way politics' (made famous by Tony Blair's New Labour project, but imitated by social democratic politicians across Europe) that offered no alternative to the neo-liberal paradigm, and in many cases deepened it. ${ }^{2}$ European integration reinforced an edifice of 'extreme centrism', through its institutional procedures of consensual law-making, constitutionalisation of the Treaty, and basic commitments to market liberalism. ${ }^{3}$ In the absence of any robust supranational

\footnotetext{
${ }^{1}$ Most notably Jürgen Habermas, declaring that since 1989, it has become impossible to break out of the universe of capitalism; the only remaining option is to civilise and tame the capitalist dynamic from within' in The Crisis of the European Union: A Response (Polity Press, 2012) 106. (This is the same Habermas who now declares Brexit the defeat of capitalism by populism, Die Zeit, 12 July, 2016,

http://www.zeit.de/kultur/2016-07/juergen-habermas-brexit-eu-crises-english.)

2 This begins earlier, with Mitterrand's climb down from a socialist programme in his first years at

President of France under pressure of the financial markets. For analysis, see L. Panitch and S. Gindin,

The Making of Global Capitalism (London, Verso 2012).

3 The term 'the extreme centre' belongs to Tariq Ali. For discussion of Brexit as representing a crisis of 'extreme centrism', see M. Wilkinson, 'The Brexit Referendum and the Crisis of Extreme Centrism' (2016) German Law Journal.
} 
democracy, this left member states with politics but without policies, and the EU with policies but no politics. ${ }^{4}$ Or, as Streeck more recently puts it in reflecting on the Euro-crisis phase, 'where there are still democratic institutions in Europe, there is no economic governance any more, lest the management of the economy is invaded by market-correcting non-capitalist interests. And where there is economic governance, democracy is elsewhere.'5

I have tried to capture the constitutional crisis of the current period as representing a reprise of 'authoritarian liberalism', revealing the politically authoritarian face of economic liberalism. 6 This phenomenon was identified by Hermann Heller as characteristic of the late Weimar regime before its collapse in 1933. ${ }^{7}$ Karl Polanyi sketched it as a more general feature of the period leading up to the interwar collapse of liberal democracy. ${ }^{8}$ In this conjunction, then as now, norms of democratic constitutionalism (especially representative democracy and legality) are bypassed in order to maintain economically liberal commitments to currency and price stability, austerity and fiscal discipline, competitiveness and the avoidance of moral hazard. But this inflection is not merely formal or impartial; it serves various class and - within the geo-political context of European integration - national interests.

It is no surprise that authoritarian liberalism is accompanied by systemic and anti-systemic challenges to the prevailing order, as alternatives are sought out, political populism returns, and authoritarian illiberalism beckons. This is most evident in Central and Eastern Europe, but is also represented in the growth in core Europe of Eurosceptic parties such as the Front Nationale and the Alternative für Deutschland. These movements and counter-movements are uneven in Europe, splintered and fragmented across the region, and yet commonalities can be identified.

The purpose of this chapter is to analyse these common themes and explore the deeper roots of 'authoritarian liberalism', conceptually and historically. It will be argued that although heightened in critical moments, the phenomenon of authoritarian liberalism corresponds to a more basic tension in the constitutional state between the forces of capitalism and democracy. This material dynamic has recently been theorised by Wolfgang Streeck, but, as yet, is missing from constitutional enquiry.9 Introducing it gives us a clearer perspective on the

\footnotetext{
4 See P. Mair, Ruling the Void (London, Verso, 2013).

5 W. Streeck, 'Heller, Schmitt and the Euro' (2015) European Law Journal 361 - 370.

${ }^{6}$ M. Wilkinson, 'The Specter of Authoritarian Liberalism: Reflections on the Constitutional Crisis of the

European Union' (2013) 14 German Law Journal_527 - 560; 'Authoritarian Liberalism in the European Constitutional Imagination: Second Time as Farce?' (2015) 21:3 European Law Journal 313 - 339; 'The Reconstitution of Postwar Europe: Liberal Excesses, Democratic Deficiencies' in M. Dowdle and M. Wilkinson (eds.) Constitutionalism Beyond Liberalism (Cambridge: Cambridge University Press, 2017) 38 - 79

7 Hermann Heller, ‘Autoritärer Liberalismus', Die Neue Rundschau 44 (1933): 289-298, (H. Heller (trans S. Paulson), 'Authoritarian Liberalism?’ European Law Journal 21 (2015): 295-301).

8 See Karl Polanyi, The Great Transformation: The Political and Economic Origins of Our Time (Boston: Beacon Press, 2001 (1944))

9 See W. Streeck, 'The Crises of Democratic Capitalism' (2011) 71 New Left Review 5 - 29; W. Streeck, Buying Time: The Delayed Crisis of Democratic Capitalism (London: Verso, 2013). But see M. Goldoni and M. Wilkinson, 'The Material Constitution' (2018) Modern Law Review, forthcoming.
} 
trajectory of European integration: from the very beginning of the post-war project through to the Euro-crisis phase, constitutional development hinges on this material dynamic.

The argument will proceed as follows. I will first outline the features of the Euro-crisis regime that characterise it as both 'authoritarian and liberal', and suggest this represents a deepening of rather than divergence from the normal path of integration (Part 2). This confluence of authoritarianism and liberalism sounds curious because, taking liberalism for political liberalism, political and constitutional theory generally elides the material and conflictual dynamic between capitalism and democracy (Part 3). To explore this further requires a historical turn, taking first the inter-war breakdown of liberal constitutionalism in Europe (Part 4) and then the post-war and post-Maastricht reconstruction, based on an economic constitutionalism, which was influenced, I speculate, by a profound misreckoning - concern for the democratic threat to liberalism subsumes the liberal threat to democracy (Part 5). This reconstruction lays the ground for the present moment, a critical but as yet inconclusive phase when authoritarian liberalism assumes more active forms in an attempt to maintain the material order (Part 6). Although in some ways reminiscent of the inter-war breakdown of liberal democracy, the outcome remains uncertain: contestation has increased but without definitive rupture, with the possible exception of Brexit.

\section{AUTHORITARIAN LIBERALISM}

The term 'authoritarian liberalism' captures two symptoms of the constitutional development of Europe. First, there is an authoritarian aspect to EU, and especially Eurozone, governance, represented by a twofold process of dedemocratisation and de-legalisation. ${ }^{10}$ This refers to the bypassing of parliamentary authority and parliamentary debate as well as the violating or circumventing of normal guarantees associated with the rule of law, including the protection of social rights. This dual development has been captured by terms such as 'executive managerialism' and 'emergency Europe'. ${ }^{11}$

But second, and underemphasised in those accounts, which focus on mutations in the formal exercise of authority, is the material nature of this authoritarianism and its historical pedigree: its aim at the maintenance of a regime

${ }^{10}$ C. Kilpatrick, 'On the Rule of Law and Economic Emergency: The Degradation of Basic Legal Values in Europe's Bailouts' (2015) Oxford Journal of Legal Studies, Vol. 35, No. 2, pp. 325-53. Kilpatrick now offers the term liminal legality, which nicely captures the legal grey area of much of the Eurozone conditionality, see 'The EU and its Sovereign Debt Programmes: the Challenges of Liminal Legality' (2017) Current Legal Problems.

11 See C. Joerges, 'A Crisis of Executive Managerialism in the EU: No Alternative?' in Trubek, D.M., de Búrca, G., Kilpatrick, C. and Scott, J. (eds) Critical Legal Perspectives on Global Governance: Liber amicorum David M Trubek (Oxford: Hart Publishing); J. White, 'Emergency Europe' (2015) Political Studies, Vol. 63, No. 2, pp. 300-18. 
of economic liberalism represents a deepening of rather than diversion from the normal path of integration. It is, in that respect, a 'conservative revolution'.

The substantive conditions imposed through the Euro-regime, by member states of the Euro-group as well as the 'Troika' of institutions (IMF, European Central Bank and European Commission), are neo-liberal 'austerity' measures (e.g. privatisation, liberalisation, labour market reforms, regressive tax increases). This demands extraordinary government intervention in society, dismantling social contracts and disrupting existing social relations. It has also been backed by class and country specific injections of central bank liquidity, particularly through the OMT programme..$^{12}$ Conditionality (hypothetically in the case of the ECB's bondbuying under OMT) is justified on the basis of the need to return to or approximate 'market conditions' of competitive economic practices, in order to avoid the moral hazard of a rescue that might incentivise further government imprudence and avoid or defer neo-liberal structural reform. ${ }^{13}$

Although these measures of conditionality impose very specific, intrusive, and debilitating constraints on debtor countries, they are consistent with and even a continuation of the liberal economic bias of the European constitution. This has evolved unevenly over the last few decades but it affects the EU as a whole, not only the Eurozone; and it affects debtor as well as creditor countries. ${ }^{14}$ This is an important point because its puts the allegedly exceptional nature of the measures in fuller context. So, although care has to be taken to distinguish particular institutional mutations in the governance of economic and monetary union, especially the new powers and authority of the Euro-group and the ECB, it is important to note that the neo-liberal bias of the Euro-crisis response is symptomatic of broader trends in EU economic constitutionalism if not necessarily demanded with any precision in the letter of the Treaty. ${ }^{15}$

The hollowing out of social democracy through the Euro-crisis in favour of technocratic market-making and enforced market-rationality is thus a feature of much longer trends. Concerns about the EU's democratic deficit long predate the financial crisis of 2008; perhaps the most well-known article on the democratic deficit was published in 2006, Hix and Follesdal depicting in painstaking detail the centrist free-market bias of the ordinary legislative procedure, and without even any discussion of the constraints imposed as a result of Economic and Monetary Union. ${ }^{16}$ In response to German Court's Maastricht ruling, Jürgen Habermas noted in 1995 that the democratic deficit was already 'expanding day by day

\footnotetext{
12 See, especially, M. Blyth, Austerity: History of a Dangerous Idea (OUP, 2013)

13 On the OMT programme, see M. Wilkinson, "The Euro is irreversible, or is it? On OMT, Austerity, and the Threat of 'Grexit" (2015) 16 German Law Journal 1049 - 1072

14 See F. Scharpf, 'The asymmetry of European Integration, or, why the EU cannot be a social market economy' (2010) 8 Socio-Economic Review 211 - 250.

${ }^{15}$ For an argument that 'downturn austerity' is better understood as an ideological prescription rather than a legal obligation within the European constitutional framework, see C. Kaupa, 'Has Downturn Austerity Really Been Constitutionalised in Europe? On the Ideological Dimension of Such a Claim’ (2017) 44:1 Journal of Law and Society $32-55$.

16 See S. Hix and A. Follesdal, 'Why there is a democratic deficit in the EU: A response to Majone and Moravscik' (2006) 44 JCMS 533 - 62.
} 
because the economic and social dynamics even within the existing institutional framework perpetuate the erosion of national powers through European law'. ${ }^{17}$ In reality, concerns amongst critical and Marxist scholars about the economically liberal bias of European integration and its impact on social democracy can be traced back to before the Single European Act and earlier (even during the socalled trentes glorieuses). ${ }^{18}$

Although forces of authoritarian rule intensify once re-politicisation is threatened, the dynamic of de-democratisation is identifiable right from the start of post-war European reconstruction. ${ }^{19}$ The difference through the Euro-crisis has been the increase in the degree of popular resistance as 'anti-austerity' social movements have been harnessed across the continent by political parties and in the case of Greece, obtained the reins of government. But if the era of permissive consensus is decisively over, there has not (as yet) been a definitive rupture of redemocratisation - either at the supranational or national level, with the possible exception of Brexit. ${ }^{20}$

If democracy was never the guiding thread of European integration, law, however, did play a central role, and right from the foundational stages. ${ }^{21}$ The transition from 'integration through law' to 'integration through fear', as Weiler characterised crisis-era Europe, therefore appears significant. ${ }^{22}$ The harnessing of fear can be captured in the new identification of a Schmittian enemy, not external and physical, but rather internal and ideological. According to Donald Tusk, the notion that there could be any alternative to austerity is a dangerous illusion. ${ }^{23}$ Tusk associates resistance to austerity as somehow 'anti-German', and speaks approvingly of ordoliberalism. The notional enemy is anyone who calls into question this new 'common sense', those 'bad Europeans' who disregard the economic stability criteria. ${ }^{24}$

A domestic electorate may of course accept the idea that 'there is no alternative' to neo-liberal structural reforms. But now that idea is imposed as a constitutional (even supra-constitutional) constraint, achieving ideological

17 J. Habermas, ‘Remarks on Dieter Grimm's 'Does Europe Need a Constitution” (1995) 1 European Law Journal, $303-307$.

${ }_{18}$ For an earlier discussion of the link between European integration and capitalist development see P. Cocks, 'Towards a Marxist Theory of European Integration' (1980) 34 International Organization 1 - 40

${ }^{19}$ See Wilkinson, note 3 above.

${ }^{20}$ Representing, according to Habermas, the victory of populism (if not democracy) over capitalism, see note 1 above. Because of the UK's distinct relationship with Europe, leaving the EU does not represent the same likelihood of rupture as would a core country, such as France, Germany or Italy, leaving. See further, Wilkinson, 'The Brexit Referendum', above.

${ }^{21}$ See e.g. A. Cohen, 'Constitutionalism without Constitution: Transnational Elites Between Mobilisation and Legal Expertise in the Making of a Constitution For Europe (1940's-1960's)' (2007) 32 Law and Social Enquiry 109 and A. Vauchez, 'The Transnational Politics of Judicialisation: Van Gend en Loos and the Making of the EU Polity' (2010) 16 European Law Journal 1.

22 See Joseph H. H. Weiler, 'Editorial: Integration Through Fear', European Journal of International Law 23 (2012): $1-5$

${ }^{23}$ See 'The Donald Tusk Interview: Annotated Transcript', Financial Times, July $16^{\text {th }} 2015$.

${ }^{24}$ See Udo di Fabio, 'Karlsruhe Makes a Referral', 15 (2014) German Law Journal 107 - 110 
hegemony despite the fact that it still seems explicitly partisan in a politicaleconomic and a geo-political sense - the crisis has emerged with clear winners and losers, between nations as well as between classes within nations. ${ }^{25}$

But the novelty of the move away from legality can also be overstated. Thus the attempt to create a loose structure of public discipline within EMU, the 'Stability and Growth Pact' - setting deficit and debt levels that were violated almost immediately by France and Germany - was under-enforced before the crisis by the European Council and the European Court of Justice. ${ }^{26}$ This fact was given relatively little attention at the time; in the era of the Open Method of CoOrdination, soft law, new governance and other softer forms of de-legalisation were celebrated by many as sensible departure from a Community method of lawmaking that was too centralised and 'one-size fits all', unable to accommodate the constitutional diversity within the Union. ${ }^{27}$

It is important to grasp the way in which heightened authoritarianism is both transformative yet also conservative of the existing constitutional order. To be sure, the Euro-regime can be said to have mutated from a nominally rule-based structure accompanied by market discipline to a discretionary order reinforced by bureaucratic power. ${ }^{28}$ And this is not a temporary suspension of normality, in response to a situation with a clearly demarcated end-point, or with the limits of a sunset clause. It is open-ended and future-oriented. But it has a conservative aim. The aim of this mutation, substantively, is not to change but to maintain the existing material constitution of Europe and its fundamental market-driven objectives.

This is not to say there is nothing new about neo-liberalism, as a specific regime of accumulation, for example, so dependent as it is on financialisation of the economy for its resource accumulation and distribution..$^{29}$ The point is rather to pursue a more basic conceptual connection between authoritarianism and liberalism in the dynamic of constitutional change. The provenance of this conjunction in earlier phases in European history, specifically in the inter-war period of late-Weimar, suggests a longer and deeper linkage. And it is to this that we now turn.

\footnotetext{
25 See Blyth, above.

${ }^{26}$ Case C-27/04 Commission v Council

${ }^{27}$ For discussion of the relation between new governance, legality and democracy, see M. Wilkinson,

'Three Conceptions of Law: Towards a Jurisprudence of Democratic Experimentalism' (2010) 2 Wisconsin Law Review 672

${ }^{28}$ For a detailed exposition, see M. Ionnanidis, 'Europe's New Transformations: How the EU Economic Constitution Changed During the Crisis' (2017) CMLR 1237 - 1282

${ }^{29}$ For a useful recent account see e.g. B. Fine and A. Saad-Filho, 'Thirteen things you need to know about neoliberalism' (2017) 43:4-5 Critical Sociology 685 - 706
} 


\section{POLITICAL AND ECONOMIC LIBERALISM OR DEMOCRACY AND CAPITALISM?}

If the confluence of authoritarianism and liberalism appears incongruous, this may be because the constitutional imagination is captured by political rather than economic liberalism. During ideological battles of the cold war period, liberalism was twinned with democracy (in Western capitalism), and opposed to authoritarian socialism (in Soviet Communism). ${ }^{30}$ This was buttressed by the 'end of history' thesis famously announced by Fukuyama, liberal democracy presented as the culmination of historical progress, a kind of Hegelian terminus après la lettre. Under the influence of Rawls and Habermas, liberalism is paired with democracy and even a certain progressive (in the sense of egalitarian) political-economic position. Both theorists located their work within the context of a really existing liberal democracy and support broadly social democratic goals.

Neither Rawls nor Habermas, however, offers the prospect of any alternative to capitalism as a matter of political economy. ${ }^{31}$ Nor, more problematically, do they offer any analysis of capitalism, of the threat that capitalism poses to the democratic order. Radical democrats and critical theorists have thus long criticised Habermasian and Rawlsian political liberalism (and not only Hayekian economic liberalism) for being insufficiently attuned to the question of power, whether it is the significance of cultural power in the struggles for ideological hegemony or the capacity for economic power to translate into or effect political domination. ${ }^{32}$ Ideology as well as capital can threaten the 'empty place of power' on which the autonomy of the political depends. ${ }^{33}$ In this view, liberalism (as well as related traditions of neo-republicanism) neglects the danger of domination arising in, but not limiting itself to, the economic and social sphere. ${ }^{34}$ It takes for granted the existence of a vibrant democratic culture, underestimates its fragility and evades the threats arising to it from within the capitalist economy. The logic of individualism, marketisation, competition and the profit motive can and do lead to

\footnotetext{
${ }^{30}$ For discussion, see e.g. P. Wagner, 'The Democratic Crisis of Capitalism: Reflections on Political and Economic Modernity in Europe' LEQS Paper No 41/2011

31 J. Rawls, Political Liberalism (Columbia University Press, 1993); J. Habermas, Between Facts and Norms: Contributions to a Discourse Theory of Law and Democracy (MIT Press, 1995).

32 See e.g. S. Wolin, 'The Liberal/Democratic Divide: On Rawls' Political Liberalism' (1996) 24 Political Theory 97 - 119; C. Mouffe, 'Deliberative Democracy or Agonistic Pluralism' (1999) 66:3 Social Research $745-758$.

${ }^{3}$ See further, M. Wilkinson, 'Public Law and the Autonomy of the Political: A Material Critique', in M. Wilkinson and M. Dowdle (eds.) Questioning the Foundations of Public Law (Hart Publishing, forthcoming).

${ }^{34}$ Rawls' own framework (unlike Hayek's version) may be thought to be compatible with social justice or even demand significant redistribution of wealth. But there remains insufficient attention given to the historical record of liberal societies in meeting its egalitarian claims (and Rawls's own egalitarian intuitions). See J. Rawls, A Theory of Justice (Cambridge, MA: Harvard University Press, 1971); cf. Gerry Cohen, Rescuing Justice and Equality (Cambridge, MA: Harvard University Press, 2008).
} 
the erosion of the solidarity and community that democracy needs in order to thrive. 35

Constitutional theorists also evade the question of economic power in a capitalist society, tending to devote their attention to the counter-majoritarian dilemma, typically evaluating the legitimacy of constitutional review of legislation to protect basic civil liberties. ${ }^{36}$ There is less attention to the impact of market freedoms on equal liberties, of justifications of the decision-making framework of the central bank, or of constitutionally restricting the micro- and macro-economic policy choices of the government, even on their impact on commitments such as equality of opportunity. Celebrations of the metaphorical 'marketplace of ideas' displace concerns over the actual marketplace of goods, capital, services and persons, and more broadly over the effects of commodification and marketisation on social relations, short of exploring marginal instances of market immorality, things 'money can't buy'. ${ }^{37}$ The dynamic of political-economic development is missed because dominant strands of legal and constitutional theory adopts a normativist method of abstract analysis, depending, say, on a fictional state of nature in the social contract tradition, a momentary legal system in the tradition of legal positivism or a moralised commitment to the rule of law in the anti-positivist constitutionalist tradition. 38

To be sure, economic liberalism has a more explicitly checkered history in its relationship with democracy. Hayek's distrust not only of social justice, but also of democracy and his flirting with political authoritarianism, is well documented. ${ }^{39}$ Identification of the pairing of political authoritarianism and economic liberalism is thus not at all new or unique to the recent Euro-crisis. The notion has been used in the context of Southeast Asian capitalism and Latin America to refer to politically authoritarian and even autocratic and dictatorial measures to implement so called 'free market economics'. ${ }^{40}$ This type of pairing is sometimes referred to as 'authoritarian neo-liberalism', associated with a turn from a relatively consensual neo-liberalism of the 'third way' to the more coercive type that emerged during the recent financial crisis. ${ }^{41}$

But there is a more general conceptual point to be made. The relative autonomy of the economic in a capitalist state - operating according to a logic of

\footnotetext{
35 See K. Polanyi, The Great Transformation: The Political and Economic Origins of Our Time (Boston: Beacon Press, 2001 (1944)). From the different context of the US, see J. Dewey, The Public and Its Problems (1926). 36 See e.g. L. Alexander (ed.) Constitutionalism: Philosophical Foundations (Cambridge University Press, 1998).

37 See M. Sandel, What Money Can't Buy: The Moral Limits of Markets (Allen Lane, 2012)

38 Rawls' own later concern (when he moves from the general theory of justice to its more particular expression in Political Liberalism) is with the stability of the political conception of justice in the face of the challenge of multiculturalism and the pluralism of comprehensive doctrines rather than in the face of the challenges of capitalism, specifically its structural tendencies towards inequality, on which, see T. Piketty, Capital in the 21 $1^{\text {st }}$ Century (Harvard University Press, 2013)

39 Cf. W. Scheuerman, 'The Unholy Alliance of Carl Schmitt and Friedrich Hayek' (1997) 4 Constellations 172 .

${ }^{40}$ See e.g. K. Jayasuriya, 'Globalisation, Sovereignty and the Rule of Law: From Political to Economic Constitutionalism', Constellations 8 (2001): 442

41 On 'authoritarian neoliberalism' see I. Bruff, ‘The Rise of Authoritarian Neoliberalism' (2014) 26:1

Rethinking Marxism 113 - 129.
} 
de-politicisation (naturalisation) of inequality, commodification of social relations, and competitive erosion of the bonds of solidarity - affects the legitimacy of the political domain of democracy and of the relationship between rulers and ruled. Liberal constitutional theory, and constitutional theory more generally, evades this dynamic, taking free market capitalism as a given. It simply does not provide the tools to deal with the pathologies and contradictions of capitalism, the tension between public goods and private interests, and the structural inequalities of power embedded in the capitalist state. These are not free-floating but constituted by and constitutive of legal and political relations.

To get a better grip on this, we must turn to work that offers a conceptualisation of these dynamics, moving towards a more 'situational' approach, a mix of historical, comparative, critical, political-economic, and geopolitical analysis. ${ }^{42}$ The division between political and economic domains then looks more blurred and inter-related, reflecting a material tension between democracy and capitalism as real political and social forces. Wolfgang Streeck has popularised this tension and it is a useful heuristic for conceptualising constitutional change. ${ }^{43}$

In the post-war period, Streeck recounts how the capitalist state is transformed from a 'tax state' during the trentes gloriueses, to a 'debt state' in the neo-liberal era beginning in the 1970 's, to a 'consolidation state' in the last decade of austerity-driven political economics, under particular pressure of the single currency. ${ }^{44}$ But the modern state also develops as a democratic state; its constitutional authority depends at root on some connection to 'we, the people'. 'The people' here represents the rhetorical and symbolic force of popular sovereignty. This represents the relative autonomy of the political realm, not only from theological power, as in classic accounts of modern secularisation, but also from economic power. It is not merely a presupposition, or a worldview. It is a fragile and ongoing material process, attained, if at all, by social struggle against the fusion of political and economic power and class rule (which does not end with feudalism). Its narrative includes worker's movements, women's movements, anticolonial movements, and other struggles for equality and recognition. ${ }^{45}$ The state can be represented as a tension between democracy and capitalism, community and coercion, solidarity and individualism (represented by the figures of the Statsvolk and the Marktvolk, as Streeck puts it). ${ }^{46}$

In this more sociologically rich account, the state can be said to represent the unity of difference between the political and economic; it is no mere inert

\footnotetext{
42 For a preliminary sketch of this approach in constitutional theory, see M. Goldoni and M. Wilkinson, 'The Material Constitution' (Modern Law Review, forthcoming).

43 See W. Streeck, 'The Crises of Democratic Capitalism' (2011) 71 New Left Review 5 - 29.

44 W. Streeck, Buying Time: The Delayed Crisis of Democratic Capitalism (London: Verso, 2013)

45 These are struggle for what Castoriadis calls 'effective autonomy', see Philosophy, Politics, Autonomy: Essays in Political Philosophy tr. D. Ames (OUP, 1991).

46 See Streeck, above.
} 
container, or abstract idea of reason, but reflects stages of democratic and capitalist development, associated, for example, with the extension of the franchise as well as the expansion of the market. ${ }^{47}$ In critical periods, when capitalism and democracy come into explicit, direct conflict, both in terms of interests and ideas, the state is increasingly 'seen' as a representation of these tensions in political economy and in some cases as a partial actor in their resolution. The reason we can talk here about the state and not just about temporary elected government is that all the institutions of the state ('the ideological and repressive state apparatus' as Althusser calls it) reinforce and recalibrate the relationship between democracy and capitalism - the military, police, judiciary, central banks, as well as cultural and media institutions. ${ }^{48}$ For those states which are members of the Eurozone, we can add to the governing apparatus the five unelected presidents, of the Commission, Council, ECB, Euro-group and European Parliament. This repressive and ideological apparatus of the state-system in Europe not only bypasses democratic accountability; it does not even have a strong democratic representative body as supplementary or corrective force.

Just as capitalism and inequality may threaten the democratic state, democratic material struggles for political and social equality may appear as a potential threat to the capitalist state. Democratic movements may threaten a basic structural re-differentiation of the political and the economic with politicaldemocratic control over the economy (in the case of democratic socialism). In such a context, in order to maintain the status quo, the ideological and repressive apparatus of the capitalist state and state-system proffers a more active form of authoritarianism. To capture the development of these material constitutional dynamics in Europe, we can now present a brief diachronic overview.

\section{INTER-WAR EUROPE: A MISRECKONING?}

In conjunctural periods, the tension between the democratic state and the capitalist state is heightened, entailing deep-seated constitutional crisis. A particularly significant moment for grappling with the structure and dynamic of European integration is the inter-war period, marking the end of the jus publicum Europeaum of the 'long nineteenth century' (from the French Revolution to the First World War). In late Weimar Germany, the democratic capitalist state reached breaking point, not only due to external factors, but because of the growing threat of a class conscious and politically emancipated proletariat which threatened the differentiation of the political and the economic established and protected by the Constitution itself. ${ }^{49}$ The reaction of the governing elite to this threat was

\footnotetext{
47 See e.g. B. Jessop, The State: Past, Present, Future (Polity Press, 2016).

48 See L. Althusser, On the Reproduction of Capitalism: Ideology and Ideological State Apparatuses (Verso, 2014 (1971))

49 The Weimar constitution promised to protect economic liberalism as well as the social state, posing a dilemma well understood by its architect, Hugo Preuss. See H. Preuss, 'The Significance of the
} 
ultimately a combination of authoritarianism and economic liberalism, as identified by Social Democrat and constitutional theorist, Hermann Heller. ${ }^{50}$

The term 'authoritarian liberalism' was thus used by Heller to denigrate the attempts of the German state in alliance with big business in the period between 1930 and 1933 to keep economic liberalism going at all costs, maintaining the differentiation of the political and the economic by violating it, intervening in the economy in favour of capitalist interests. ${ }^{51}$ Heller's target with the label was not only the centrist Cabinets of Chancellor Brüning that governed Germany before the Nazi party took power, but also the constitutional theorist who had advised them, Carl Schmitt. ${ }^{52}$ Schmitt had recommended a strong state in order to keep the free market economy going against the threat of democratic socialism and experiments of economic democracy, encapsulated in his address to the Langnamverein in 1932, 'strong state, free economy'. 53

The Brüning cabinets bypassed parliamentary democracy, using presidential decrees under cover of emergency, in order to impose austerity and defend the social relations of capitalism and economic liberalism - competition, the profit motive, accumulation, private property, and social inequality. ${ }^{54}$ The aim of this formation was the frustration of any democratic solidarity, in order to maintain the capitalist form of the economy, in a critical period of deflation, high unemployment and political turbulence. For authoritarian liberals, the fear in these conditions was that democracy might turn towards socialism (a fear heightened by the earlier Bolshevik victory in the Soviet Union). ${ }^{55}$

This pattern of authoritarian liberal response and reaction to economic crisis was far from unique to late Weimar - right across the globe countries tried to maintain the political-economic demands of the Gold Standard, fiercely resisting social democratic programmes, until, eventually but unevenly, countries abandoned Gold, and market liberalism, leading, for example, to Welfarism in

\footnotetext{
Democratic Republic for the Idea of Social Justice' in A. Jacobson and B. Schlink (eds.) Weimar: A Jurisprudence of Crisis (University of California Press, 2000).

50 Hermann Heller, ‘Autoritärer Liberalismus', Die Neue Rundschau 44 (1933): 289-298, (Hermann Heller (trans S. Paulson), ‘Authoritarian Liberalism?’ European Law Journal 21 (2015): 295-301).

51 ibid

52 This approach to social democracy wasn't restricted to the German authoritarian liberals. Austrian liberal von Mises noted that despite the dangers of fascism and its makeshift nature, it will be forever acclaimed for saving the continent from socialism and the attendant dangers to private property, approving Engelbert Dolfuss's crushing of labour and social democracy in Austria in the 1930's. For further discussion, see Alexander Somek, 'Austrian Constitutional Doctrine 1933 to 1938', in Christian Joerges and Navraj Singh-Ghaleigh (eds.) Darker Legacies of Law in Europe 361, 362 (Hart Publishing, 2003). In 1935, the cabinet of Laval in France undertakes authoritarian measures to save the Franc under enabling laws that bypass ordinary parliamentary debate, see Loewenstein, 'Autocracy versus Democracy in Contemporary Europe' (1935) The American Political Science Review, 571 - 593.

53 See Carl Schmitt, 'Strong State, Sound Economy', reprinted in Cristi, above.

54 For a full account, see E. Kolb, The Weimar Republic 2nd ed. (Routledge, 2005) 116 - 135

55 Cf. R. Cristi, Carl Schmitt and Authoritarian Liberalism: Strong State, Free Economy (University of Wales Press, 1998).
} 
Britain and the New Deal in the US. ${ }^{56}$ According to Karl Polanyi, the more fiercely countries resisted social democracy through authoritarian government in the name of economic liberalism and sound finances, the stronger and fiercer the eventual backlash would be (the 'double movement'). Authoritarian government hollowed out democracy, ultimately weakening its ability to respond to the Fascist threat when it arrived. It was, in other words, authoritarian liberalism that prepared the ground for Fascism. ${ }^{57}$

Heller's own earlier considered view was that conditions of extreme socioeconomic inequality were incompatible with the survival of a constitutional democracy, because democracy requires a certain degree of social homogeneity, or at least the prospect of such, to sustain political legitimacy. ${ }^{58} \mathrm{He}$ had warned presciently in 1928 that the relative tranquillity in the Federal Republic would be short-lasting because social homogeneity was 'lacking to an extent unmatched in previous eras. ${ }^{59}$ Capitalism, in other words, was a threat to the constitutional order.

Yet the message taken by mainstream constitutional theory in response to this extraordinary double movement and the breakdown of liberal democracy it entailed in Germany (and elsewhere) would be quite different from the one Heller and Polanyi had conveyed. It was not the threat that economic liberalism (or capitalism) posed to democracy that resonated in the liberal constitutional imagination but the threat that democracy posed to liberalism. This came to prominence through the work of another constitutional theorist of the period, who had emigrated to the US, but became closely involved in post-war German reconstruction, Karl Loewenstein. Loewenstein, writing in 1935, thought that liberal democracy needed to be more 'militant' in the fight against Fascism (and, if to a lesser extent, also against Communism). ${ }^{60}$ The structures of the Weimar republic should have been more flexible in order for it to defend itself, by suspending constitutional rights, banning political parties, preventing extremist groups and associations. Lowenstein, describing the opportunism of the Fascist opponents of the constitution, urged liberal democracy to pre-empt them, take the fight to its enemies, if necessary to 'fight fire with fire', echoing Carl Schmitt's own call for robust defence of the Weimar constitution, by dictat and decree. ${ }^{61}$

\footnotetext{
56 See Karl Polanyi, The Great Transformation: The Political and Economic Origins of Our Time (Boston: Beacon Press, 2001 (1944)).

${ }^{57}$ It was reaction to the 'deadlock of the market system' that precipitated the 'conjoint disintegration' of the political and economic system across the globe. Although reactions were similar only in discarding laissez-faire principles, where liberals obstructed social and economic reforms that might involve planning, regulation or control, 'the victory of fascism was made practically unavoidable'. Rejecting purely local or historical explanations for the situation that gave birth to Fascism, 'in reality', Polanyi insists, the part it played was determined by one factor: 'the condition of the market system', ibid, at $250-265$.

${ }^{58}$ H. Heller 'Political Democracy and Social Homogeneity' in A. Jacobson and B. Schlink (eds) Weimar: A Jurisprudence of Crisis (Berkeley, University of California Press, 2000).

59 ibid, 262

60 See K. Loewenstein, 'Militant Democracy and Fundamental Rights Part 1', The American Political Science Review 3 (1937): 417 - 432 and 'Autocracy versus Democracy in Contemporary Europe Part 1', The American Political Science Review 29 (1935): 571 - 593.

${ }^{61}$ Ibid, 432
} 
In the aftermath of World War II, mainstream political and constitutional theory became preoccupied with liberal constitutional defence, neglecting the sociological examination of the power structures that could formally and informally undermine democracy in a capitalist state. The German example of entrenching strong constitutional guarantees became increasingly influential and widespread (however misleading the conventional narrative of the dignified reaction to Nazism). ${ }^{62}$ Constitutional lawyers, and those tasked with designing legal and political institutions, were set to offering justifications for various institutional arrangements - whether domestic, international or supranational that would constrain majoritarianism, with the rationale (or pretext) of preventing democratic backsliding or avoiding democratic irrationality. Independent technocratic institutions such as constitutional courts, commissions, and central banks became the norm, and were gradually engrained in the liberal constitutional imagination. European integration was an intrinsic part of this post-war settlement, representing the construction of a militant democracy 'writ large'.

But as Jan-Werner Müller has recounted, 'restrained democracy' is a more accurate representation of this phenomenon than the inappositely named 'militant democracy'.63 If anything, it was liberalism that was to be militantly protected, albeit in the name of democratic consolidation. ${ }^{64}$ This militancy was driven more by concerns to keep the wheels of economic liberalism revolving than to defend political liberalism, still less to promote strong democracy.

In constitutional enquiry, the focus undoubtedly was on the dangers of strong (unfettered) democracy, rather than, as Heller and Polanyi had warned, of unfettered capitalism and its tendency towards socio-economic inequality. If in political practice, the excesses of capitalism as much as democracy were tempered in the trentes glorieneses, through the building of the welfare state and various forms of corporatism and social democracy, this did not capture the attention of constitutional scholars, lawyers and constitution-builders. The seminal texts of liberal political and constitutional theory were preoccupied with resolving the counter-majoritarian dilemma through various devices of justification for constraints on the democratically determined will of the majority, both institutionally (constitutional review) and ideologically (as in the Rawlsian device of 'reasonableness'). ${ }^{65}$ The fragility of the constitution in the absence of constitutional review, and even legal positivism's relativising of the question of legitimacy, is blamed by constitutional theorists and legal philosophers for Weimar's collapse. ${ }^{66}$ Capitalism passes under the radar.

\footnotetext{
62 See M. Hailbronner, Tradition and Transformations: The Rise of German Constitutionalism (OUP, 2015).

63 See Jan-Werner Müller, Contesting Democracy: Political Ideas in 20 th Century Europe (Yale University Press, 2011)

64 ibid

65 See Rawls, Political Liberalism, above.

66 See Lon Fuller, 'Positivism and Fidelity to Law - A Reply to Professor Hart', Harvard Law Review 71 (1958): 630 and Müller, Contesting Democracy, above, 129. Cf. F. Neumann, Behemoth: The Structure and Practice of National Socialism 1933-1944 (Ivan Dee, Chicago, 2009 (1942)).
} 
Mainstream constitutional theory thus leads away from any critical engagement with political economy. European integration itself - to the extent it is given any attention by constitutional scholars - is seen as an aspect of the broader project of restrained democracy, rather than a further stage in the reconstitution of the relation between politics and economics in the process of democratic capitalist development. Its creation of an internal market is seen tamely and benignly as designed merely to ensure peace and prosperity for all after half of century of war and destruction. Heller's and Polanyi's lessons and the democratic struggles for equality at their heart could then be forgotten, particularly as post-war growth masked the underlying issue of socio-economic inequality. Might this prove to be a misreckoning of calamitous proportions?

\section{ECONOMIC CONSTITUTIONALISM IN POST-WAR EUROPE}

What is clear is that the post-war constitutional imagination in Europe was not characterised by any vision of a vibrant democratic state. It was encapsulated in the story of West German post-war constitutional development: 'we are (afraid of) the people' ${ }^{67}$ Reaction to this fear entailed a new vision not only of the governing function (in particular the technocratic functioning of government) but of the governing relationship, the relation between state and society, specifically of the nature and limits of the right to rule over the economy. In other words, this is a vision of de-democratisation both of the constituent and of the constituted powers, of sovereignty and of government. It lays out a new vision of political society, of the individual as a market participant rather than a political citizen.

This vision was presaged in the work of the ordo-liberals, whose founding meeting in Freiberg coincided with Schmitt's address to the Langnamsverein, 'strong state, sound economy'. ${ }^{8}$ Sharing Schmitt's vehement anti-communism, obsession with order, distrust of economic democracy, and belief in a strong state, they nevertheless presented unfettered capitalism (and not only democracy) as a challenge to the competition-based market society. ${ }^{69}$ Carl Joachim Friedrich identifies the ideological and constitutional significance of this 'new liberalism' as early as 1955. He notes how in Germany it signals a fundamental re-ordering of the basic ideas underpinning constitutional theory. ${ }^{70}$ As Friedrich understood, and

\footnotetext{
${ }^{67}$ See C Möllers, 'We are (afraid of) the People: Constituent Power in German Constitutional Thought', in M Loughlin and N Walker (eds) The Paradox of Constitutionalism. The UK may be an exception to this, along with the sustained democracies of the Nordic countries.

${ }^{68}$ On the link between Schmitt and the ordoliberals, and the significant of both for the Euro, see W. Bonefeld, 'Authoritarian Liberalism: From Schmitt via Ordoliberalism to the Euro' (2017) 43(4) Critical Sociology.

${ }^{69}$ Although it was already Franz Neumann who had identified the threat of organised capitalism to the rule of law in the 1920's. See F. Neumann, 'On the Preconditions and the Legal Concept of an Economic Constitution', in O. Kirchheimer and F. Neumann (eds.) Social Democracy and the Rule of Law tr. L. Tanner and K. Tribe (London, Allen and Unwin, 1987). See further, W. Scheuermann (ed.), The Rule of Law Under Siege (University of California Press, 1996)

${ }^{70}$ C J Friedrich, 'The Political Thought of Neo-liberalism', American Political Science Review 49 (1955).
} 
as Foucault would later explore in his lectures on neo-liberal governmentality in 1979, the decisive theoretical turn triggered by German ordoliberalism had been to replace constituent power (or popular sovereignty) with individual economic freedom - a freedom to participate in the market — as the legitimating device for the whole constitutional order. ${ }^{71}$ It is not only a question of delegating power to technocratic agencies to avoid temporary democratic impulses, but a basic elision or denial of political freedom. This reversed the original meaning of the economic constitution, which for Franz Neumann had meant democratic control of the economy. ${ }^{72}$ Instead, the constitution itself becomes sovereign, emblematically in post-war Germany with the idea of an inviolable 'eternity clause' in the Grundgesetz:

For the ordo-liberals, the new economic constitutionalism, based on formal equality, individual economic rights and competition, was intended to achieve the complete abolition of class as well as national conflicts from the political domain. ${ }^{73}$ The class-conscious democratic struggles of the inter-war period would be repressed in order to secure political and economic stability, considered threatened by the democratic forces that the inter-war period had unleashed. The new civil religion for the post-war order would be fiscal prudence, efficiency and competition, the model of the German economic miracle. Democracy would be restrained not (only) for fear of its violating civil or political rights but out of concern for its impact on economic stability. ${ }^{74}$ The strong state would protect the market economy, and disarm any democratic (or capitalist) threat to it.

Although it was far from straightforwardly applied (in practice softened by the Social Market economy and aspects of corporatism), this reconfiguration of the constitutional imagination would become ideologically ascendant, first in Germany and then elsewhere, not least through its influence on the process of European constitutionalisation. The self-understanding of constitutional actors in Europe (in particular the ECJ and the European Commission) would be increasingly conditioned by ideologies and interests that correspond to economic rationality and the logic of market competition. ${ }^{75}$ These trends become more acute in time and of course extend far beyond the EU. ${ }^{76}$

With the Treaty of Maastricht, the differentiation between politics and economics is taken to a new stage in the constitution of Economic and Monetary Union (EMU), establishing a division between supranational monetary policy and national fiscal autonomy. EMU is based on the twin pillars of (a) the separation of

\footnotetext{
${ }^{71}$ Friedrich, ibid; Michel Foucault, The Birth of Biopolitics — Lectures at the College de France 1978-1979 (New York, Palgrave MacMillan, 2008)

72 See Neumann, above.

73 See E V Bonn, Standard Texts on Social Market Economy: Two Centuries of Discussion (ed. Horst Friedrich Wunsche) tr. Derek Rutter (Stuttgart, Gustav Fisher Verlag, 1982) ix.

74 See J. W. Müller, Contesting Democracy: Political Ideas in Twentieth Century Thought (Princeton University Press, 2012)

75 See, e.g., E. J. Mestmäcker, 'European Touchstones of Dominion and Law' (2007) The Ordo Yearbook of Economic and Social Order 4.

76 See Kanishka Jayasuriya, 'Globalisation, Sovereignty and the Rule of Law: From Political to Economic Constitutionalism', Constellations 8 (2001): 442.
} 
monetary policy and fiscal authority and (b) the avoidance of moral hazard. In this configuration, a Member State's ability to spend and repay its existing debts would be based on its own ability to raise resources and, - increasingly in the era of the 'debt state' (and not least due to tax arbitrage in a world where capital moves relatively freely)-, this was increasingly undertaken through financial borrowing. ${ }^{77}$

The new stage of EMU must thus be understood in the broader context of neo-liberal globalisation of the 1980s, and the global turn to financialisation of the economy. ${ }^{78}$ This incorporated a loosening of capital controls, with the free movement of capital eventually becoming a fundamental legal and even constitutional right in the EU. But with its commitment to a de-politicised monetary policy based exclusively on price stability; and an independent but limited European Central Bank [ECB] with restricted monetary tools but without the guidance of any supranational economic policy capable of dealing with uneven development, socio-economic heterogeneity, or exogenous fiscal shocks, the Maastricht Treaty attempted to supranationalise ordo-liberal principles designed for domestic constitutional consumption. ${ }^{79}$

Maastricht would also signal a reversal of the previous, functional logic that economic integration would prompt political integration, and that politicisation would then force elites to engage mass publics in European matters, precipitating a process of Euro-democratisation. ${ }^{80}$ On the contrary, it removed an important lever of power from the political pillars of the Member States, but without reconstructing it at the supranational political level or establishing any plans to do so. And the new currency - a 'currency without a state' - was not only democratically unaccountable (which would hardly have differentiated it from national variants); it also lacked the social and political bonds of community to sustain it, offering a symbol of the new 'economic Messianism' of the era to follow. ${ }^{81}$ To reprise Streeck's heuristic, it seemed a decisive victory for capitalism over democracy, just as commentators were proclaiming the end of history.

\section{EURO-CRISIS: AN INCONCLUSIVE CONJUNCTURE?}

The post-war liberal constitutional imagination, though far from democratic, is more passively than actively authoritarian. It is technocratic, institutional, and juridical in form. In substance it is economically liberal, dedicated to expanding markets, pursuing free trade and spreading economic rationality. Politically, it is

\footnotetext{
77 See Streeck, above.

78 See e.g. A. Menendez, 'The Existential Crisis of the European Union' German Law Journal 14 (2013): $453-526$

${ }^{79}$ See K. Tuori and K. Tuori, The Eurocrisis: A Constitutional Analysis (CUP, 2012).

80 See Gary Marks and Lisbet Hooghe, 'A Postfunctionalist Theory of European Integration: From Permissive Consensus to Constraining Dissensus’ British Journal of Political Science 39 (2009): 1-23, at 5.

81 See Michael A. Wilkinson, 'Economic Messianism and Constitutional Power in a German Europe: All Courts are Equal but Some Courts are More Equal Than Others' (2014) LSE, Law, Society and Economy Working Papers, 26/2014, available here: http://papers.ssrn.com/sol3/papers.cfm?abstract_id=2522919
} 
moderate, extreme only in the centrism it espouses and the technocratic and managerial ethos it embodies. Democracy is restrained but not yet extinguished.

But this hollowing out of democracy presages the more active authoritarianism to come. Although democracy had never been a key component of the post-war construct, since Maastricht, it would be systematically over-ridden, and not only in parliaments but in popular referenda. ${ }^{82}$ And when the Euro-crisis hits, liberal centrism struggles to hold, becoming subject to increasing political contestation, sometimes from the margins but sometimes from positions of governmental power. Having lost faith in normal institutional routes, the apparatus of the state (and European state system) increasingly resorts to cajoling and coercing, undermining even its own moderate checks and balances of constitutional accountability in an attempt to maintain order. Since the democratic support for liberal centrism was always thin, it can only compensate in other ways, presenting those who contest it as irrational, unreasonable or un-European. Fear becomes its method in a more overt manner. If its success was apparent in the Greek crisis, its limits may have been revealed through the recent Brexit referendum.

To be sure, the Euro-crisis suggests that the material order of democratic capitalism in the European state-system is complex. The interests of capital are not always unified or aligned. They may diverge, marked by contests between Capitals as much as between capitalism and democracy. Authoritarian liberalism thus now needs to capture not only de-democratisation and de-legalisation in combination with the aim of a substantively liberal economic order, but the hegemonic relations between Capitals in a new 'German Europe', where every country is urged to be more like Germany despite the impossibility of such a demand. 83

But this suggests that the constitutional crisis is not primarily about a conflict between emergency politics and the normal rules of the game. These have been relatively easily bent or circumvented when necessary. They are rather surface indicators of a deeper crisis of the material constitution. The 'rules' of the economic liberalism established by EMU (ordo-liberal in content) - e.g. no central bank financing, no bail-out of countries in financial difficulty, the avoidance of moral hazard, emphasis on price stability - come into conflict with the imperative to maintain the symbol of economic integration, the single currency (e.g. the euro is 'irreversible', 'if the Euro fails, Europe fails'). In turn, they both come into conflict with the democratic and social movements against austerity, and in the case of Greece this was pushed (nearly) to the limit with the election of an antiausterity but pro-European government. Democracy and the rule of law, including the protection of social rights, are also nominally protected in the EU Treaties and its charter of fundamental rights, it must be recalled. There is, in other words, a

\footnotetext{
82 The most conspicuous warning sign was surely the Dutch and French rejection of the EU Constitutional Treaty in 2005, which was followed by its repackaging in the Lisbon Treaty.

${ }^{83}$ See Helen Thompson, 'Austerity as Ideology: The Bait and Switch of the Banking Crisis' (2013) 11 Comparative European Politics 729 - 736.
} 
clash of fundamental political objectives: ordoliberalism, European integration, and democratic self-government.

Democratically legitimate rescue would require a transnational solidarity that is proscribed by ordoliberalism and cannot simply emerge through a functional spill-over effect. The institutional channels for it to be expressed do not exist. The result is rescue by the back-door, in super-technocratic fashion, as the ECB and the powerful members of the Euro-group take centre stage. The irresistible force of neo-functionalism then meets the immovable object of ordoliberalism and the German hegemony that it represents. This is not only an order of rules, but also an order of interests, predominantly those of a German political class for whom export-oriented policy is a raison d'état. ${ }^{84}$

The circle is squared by permitting rescue, not as an act of democratic solidarity, but through a 'grey area' of Union law, and with strict conditionality attached. ${ }^{85}$ In this way the narrative of moral hazard is switched from the risky behaviour of private creditors to the profligacy of public debtors - the greatest 'bait and switch' in history, as Mark Blyth calls it. 86 This permits a moralisation of the debt, and a (misleading) metaphor to take hold of the imagination, that of the frugal Swabian household, which saves before it spends. Fiscal indiscipline is avoided in substance, because states have to pursue the austerity programmes (the 'strict conditionality') that are said would be demanded were they still subject to the financial markets. States - and the banks they are indebted to - are rescued enough to avoid immediate default, but without the debt restructuring that would be necessary to escape future dependency. The Eurozone thus develops in a neocolonial manner, along the lines of a core-periphery relationship between 'creditor' and 'debtor' nations. Germany becomes the 'reluctant hegemon', and the Greek people are 'punished' for electing a left-wing government that dared to oppose the austerity agenda of the Troika and powerful members of the Euro-group, only to capitulate to the 'TINA' narrative ('There Is No Alternative', to neo-liberal structural reform). ${ }^{87}$ The domestic clash between capitalism and democracy is displaced into a neo-colonial regime of integration; but it is democracy that pays the price.

Neo-functional rescue and ordo-liberal discipline can theoretically be maintained for the moment in a very tense and delicate balance. The long-term cost to the normative values of democracy, solidarity, social rights, and legality, however, has yet to be calculated. Political equality has rarely looked so illusory, as relations between debtor and creditor countries came to resemble conditions of 'unconditional surrender'. 88

\footnotetext{
84 ibid

85 See A. Menendez, 'The Existential Crisis of the European Union' German Law Journal 14 (2013): 453 526

86 Mark Blyth, Austerity: The History of a Dangerous Idea (Oxford, OUP, 2013)

${ }^{87}$ See Philip Altermann, 'Jürgen Habermas' verdict on the EU/Greece Debt Deal - Full Transcript', The Guardian, 16 th July 2015.

${ }^{88}$ See F. Scharpf, 'After the Crash: A Perspective on Multi-Level European Democracy' (2015) 21

European Law Journal 393
} 


\section{CONCLUSION}

Considered in the longue duree of the battle between economic liberalism and social democracy, Maastricht has been described as having put a decisive end to the European civil war between right and left that took place across the 'short twentieth century'. It signalled the triumph of economic liberalism. The victory of capitalism itself was even declared complete. As Etienne Balibar frames it, reflecting on the (re-) birth of the EU at the Treaty of Maastricht, what is extraordinary is the explicit and detailed setting of its liberal political-economic goals into rigid constitutional guarantees:

'The EU in its constitutive moment (Maastricht) was endowed with a quasiconstitution... where, for the first time in this part of the world... a principle of political economy deriving from a specific ideological discourse (namely neoliberal deregulation and unrestricted competition, believed to produce 'optimal allocation of resources' and spontaneously 'just' redistribution) was presented as the sovereign rule which all member states ought to implement in their national policies under close surveillance of the federal (or quasi-federal) organs of the Union...'89

If the argument of this chapter is accepted, however, this battle, or at least its preliminary stages, may have already long been lost. Once politics is reduced to a single political-economic logic, and the possibility of genuine renewal comes down to the possibility of exercising the constituent power, the autonomy of the political is reduced to a bare formality or the prospect of a revolutionary rupture. This resettlement occurs right at the beginning of the project of integration, and is cemented at Maastricht, rather than overturned.

In theory and practice, post-war constituent power is (temporarily) absorbed into a new regime of constituted power, based on constitutional rights, protected by constitutional courts, and managed by other technocratic institutions. But this also signifies a cultural and material shift, captured in the fear of political freedom, so emblematic of the German case but also affecting countries with a limited experience of democratic self-government. Issues of appropriation, distribution and production are increasingly taken out of the public political sphere of contestation, and determined by market logic, or the technocratic bodies who are supposed to replicate it. De-democratisation is a more appropriate term for this process that de-politicisation, given that these were highly politicised changes. And to capture constitutional change is to capture not only formal channelling but also constitutional framing, the way political debate is to be organised, and what its

89 E. Balibar, 'The Rise and Fall of the European Union: Temporalities and Teleologies' (2014) Constellations $202-212$. 
limits are. ${ }^{90}$ So the process of de-democratisation can effectively be constitutionalised not only through institutional means but also through political ideology, such as in the 'TINA' refrain.

If the constitutional implications of neo-liberal political economy are underscored by the reconstitution of Europe right from the beginning of the postwar period, the current conjuncture has thrown this settlement into doubt, but not yet into oblivion. It has been strongly contested, but there has been no definitive rupture, with the possible exception of Brexit.91 If the capitulation of Greece suggests authoritarian liberalism may survive, developments elsewhere, as rightwing Eurosceptic parties surge in popularity, suggests that the authoritarian liberal suppression of the democratic voice may, once again, tend not only to the victory of capitalism, but also to the resurgence of reactionary forms of authoritarian illiberalism. Whether any reprisal of the inter-war breakdown of liberal democracy will more closely resemble tragedy or farce remains to be seen.

\footnotetext{
90 As Gavin Anderson puts it, 'constitutional discourse is always more than the rules it generates or legitimates..., setting the parameters not just for how politics is contested, but what is deemed politically contestable'. See G. Anderson, in S Gill, New Constitutionalism and World Order (Cambridge, CUP, 2015) 283, quoting Emilios Christodoulidis.

${ }^{91}$ The UK is one of the few places in Europe to have avoided the 'Pasokification' (virtual annihilation) of the traditional centre left party, the UK Labour party under Jeremy Corbyn performing extraordinarily well in comparison to its sister parties. It is therefore a possibility that the UK's departure from the status quo of EU membership might, ironically given its advanced neoliberal trajectory, lead not to a right-wing authoritarian illiberalism, but to a turn toward democratic socialism.
} 